\title{
Piotr Ciesielski
}

Uniwersytet Mikołaja Kopernika w Toruniu

\section{Podręcznik dla projektantów komunikacji?}

\author{
Recenzja ksiązki: Jorge Frascara, Communication \\ design: principles, methods and practice, \\ New York: 2004, Allworth Press, ss. 208.
}

Dublikacja Jorga Frascary należy do względnie nielicznej kategorii dzieł poświęconych communication design. Należy ją przy tym traktować raczej jako podręcznik akademicki, a nie rozprawę naukową. Tę właśnie perspektywę uwzględnia niniejsza recenzja, która odnosić się będzie do kilku zasadniczych kwestii, kolejno zawartości książki, jej formy i języka oraz możliwości jej akademickiego wykorzystania.

Na dzieło J. Frascary składa się siedem rozdziałów. Pierwszy poświęcony jest opisowi pola communication design, drugi - jego historycznemu kontekstowi, trzeci zasadom designu (w tym jego wymogom funkcjonalnym), czwarty natomiast metodom i planowaniu. Piąty rozdział poświęcony został praktyce zastosowania designu. Szósty - relacjom między technologiami komputerowymi a projektowaniem komunikacji. Ostatnia i zarazem najkrótsza część pracy dotyczy kwestii kulturowych i społecznych designu.

W rozdziale pierwszym autor wprowadza pojęcie designu oraz przedstawia różne sposoby jego rozumienia. Dalej przedstawia rolę designera i konfrontuje ją z innymi profesjami. Wartościowe jest też wprowadzenie, a właściwie wyjaśnienie koncepcji informacji, nadmiaru (redundancy) i szumu/zakłóceń (noise). Interesujące wydają się też rozważania na temat kreatywności i jej zależności z komunikacją oraz związków tej ostatniej z estetyką. Rozdział kończy się przemyśleniami na temat głównego celu projektowania komunikacji wizualnej. 
Sporo miejsca poświęca Frascara rozróżnieniu na design traktowany jako obiekt lub właściwość obiektu oraz na czynność projektowania. Ze względu na właściwości języka angielskiego i jednoczesne funkcjonowanie słów "design" i „to design" takie rozważania są konieczne, jednak trudne do bezpośredniego przetłumaczenia na język polski, w którym często posługujemy się synonimicznie pojęciami "design”, „projekt” "wzór" i „projektować", z których jednak żadne nie wypełnia całkowicie pola znaczeniowego pojęcia "design".

W rozdziale drugim J. Frascara przedstawia historyczne uwarunkowania designu, przy czym bardziej szczegółowo opisuje dopiero design XIXi XX-wieczny. Szczególnie interesujące dla medioznawców i dziennikarzy mogą być obszerne opisy rozwoju liternictwa i właściwości poszczególnych czcionek.

Kontekst historyczny potraktowany został przez autora dość pobieżnie. Odczuwalny wyraźnie jest tu brak rozważań na temat tego, jak design był traktowany oraz kiedy datuje się jego powstanie z uwzględnieniem kontrargumentów i różnych koncepcji. Zaletą tej części pracy są natomiast liczne ilustracje, które doskonale obrazują zawartość kolejnych akapitów tekstu.

Trzeci rozdział poświęcony został zasadom design ze szczególnym uwzględnieniem jego wymagań funkcjonalnych. W kolejnych podrozdziałach poruszane są kwestie postrzegania, interpretowania i odczytywania znaczeń, a następnie języka oraz aspektów nadawania znaczeń. Wśród teorii łatwo wyłowić liczne ilustracje i przykłady, a także cenne wskazówki dla początkujących designerów, dotyczące zarówno wyboru kanału oraz formy, jak i znaczenia kontekstu, w jakim komunikat ma się pojawić.

Rozdział ten jest chyba najmocniejszym punktem podręcznika. Odczuwalna jest wyjątkowa zręczność autora $w$ formułowaniu myśli w taki sposób, by przy użyciu minimalnych środków przekazać maksimum treści. Przekazywana na kartach książki wiedza ma uporządkowaną strukturę, nierzadko jednak opiera się na truizmach.

W rozdziale czwartym J. Frascara przedstawił metody pracy designera oraz sposoby planowania pracy/przeprowadzania działań. Proces projektowania zdaniem autora przebiega, a raczej powinien przebiegać, w dziesięciu kolejnych etapach: 


\section{Zlecenie projektu i towarzysząca temu pierwsza definicja problemu i szacunek budżetu}

2. Zbieranie danych

3. Druga definicja problemu

4. Zdefiniowanie celów

5. Trzecia definicja problemu

6. Wytworzenie propozycji projektu

7. Prezentacja zleceniodawcy

8. Organizacja produkcji

9. Nadzór nad implementacją

10. Ocena skuteczności/wydajności (performance)

Trudno z całą pewnością uznać, że ten model procesu projektowania ma zastosowanie dla każdej branży, zwłaszcza że zauważalne jest zróżnicowanie procesu twórczego w zależności od podmiotu. Warto jednak zauważyć, że ten sposób prowadzenia procesu designu jest wyczerpujący (tj. kompletny) i atrakcyjny dla początkujących projektantów.

Rozdział piąty jest szczególnie interesujący ze względu na jego zawartość praktyczną. Podzielony na podrozdziały o designie informacyjnym, perswazyjnym, edukacyjnym i administracyjnym, dotyka zaledwie kilku istotnych kwestii związanych z praktyką projektantów informacji. Ten niedługi fragment książki można określić mianem ogólnikowego, jego zaletą jest jednak to, iż uzmysławia czytelnikowi, jak szerokie pole obejmuje swym zakresem communication design i zachęca do poszerzenia swej wiedzy na ten temat.

Rozdział przedostatni poświęcony jest możliwościom, jakie dają technologie komputerowe projektowaniu komunikacji. Uwagi poczynione w tej części pracy może i są mało odkrywcze, ale za to porządkują doświadczenia designerów związane z upowszechnieniem się nowych mediów i technologii oraz przedstawiają obraz przemiany, jakiej uległ zawód projektanta za sprawą możliwości, jakie dają komputery.

Ostatni, krótki fragment książki wydaje się dolepiony i nieukończony. Trudno wystawić mu ocenę, można jedynie zadowolić się spostrzeżeniem, że kulturowe i społeczne uwarunkowania (ale i rezultaty oddziaływania) designu wymagają znacznie szerszego opracowania. 
Struktura podręcznika jest przejrzysta i przyjazna czytelnikowi. Liczne ilustracje dobrze obrazują treści wyrażone werbalnie. Język, jakim posługuje się Jorge Frascara, jest niezwykle prosty i przyjazny w odbiorze, nawet dla osób, które nie posługują się biegle językiem angielskim. Do większości rozdziałów można wysunąć zarzuty o zbyt płytkie omówienie istotnych kwestii, do tego autor nierzadko posługuje się truizmami i przedstawia oczywistości. Ze względu na te właściwości tekstu można powiedzieć, iż jego zaletą jest raczej porządkujący charakter publikacji niż jej nowatorstwo, nawet mimo tego, iż dotyka ona zagadnień o nielicznej reprezentacji w literaturze.

Podręcznik Communication Design... należy traktować niemal wyłącznie jako wprowadzenie $w$ ramy zagadnień dotyczących projektowania komunikacji. Należy przy tym zauważyć, że ograniczenia te są spójne z ambicjami autora, który swoje dzieło kieruje właśnie do studentów rozpoczynających edukację w tym zakresie oraz do praktyków, którzy stoją u progu kariery w roli designerów. Niewątpliwe zalety publikacji to jej zrozumiały język oraz czytelna struktura, a także uporządkowanie zagadnień. Należy ocenić ją wysoko z perspektywy podstawowego podręcznika, który przedstawia zarys problematyki communication design, jednak należy pamiętać, że nie tyle nie zawiera ona kompletnej wiedzy, co wskazuje kierunki, w jakie zainteresowany czytelnik powinien skierować swą uwagę. 